Kinestetik : Jurnal Ilmiah Pendidikan Jasmani 5 (4) (2021)

Kinestetik : Jurnal Ilmiah Pendidikan Jasmani

https://ejournal.unib.ac.id/index.php/kinestetik/index

DOI : $10.33369 /$ jk.v5i4.19688

\title{
THE DEVELOPMENT OF PHYSICAL ACTIVITY MODEL THROUGH A CIRCUIT GAME TO DEVELOP THE BASIC LOCOMOTOR MOVEMENT ABILITY FOR EARLIER ELEMENTARY STUDENT
}

\author{
Yudanto $^{1 *}$, Kristi Utami ${ }^{2}$
}

${ }^{1}$ Sport Education, Faculty of Sport Science, Universitas Negeri Yogyakarta, Indonesia

\begin{tabular}{l} 
Article Info \\
\hline Article History : \\
Received : December 2021 \\
Revised : December 2021 \\
Accepted : December 2021 \\
Available online : December \\
2021
\end{tabular}

\section{Keywords :}

Circuit Games, Locomotor Basic Movement, Earlier Elementary Student

\begin{abstract}
This research aims to produce a product of a physical activity model through a circuit game to develop the basic locomotor movement ability for an earlier elementary student. This research is development research. The procedures or steps that were used in this study, namely: 1 ) analyzing the product, 2) developing the initial product, 3) expert validation and product reliability testing, 4) small and wide-scale trials, 5) revisions products, 6) organizing of the final product. The validation test was using content validation and the reliability was using the Crude Index Agreement, the results of the reliability test obtain a coefficient of $0.75-0.81$. The small-scale trials were conducted at SD Negeri Karangjati and the large-scale trials were conducted at SD Negeri Mlesen and MI Husnayain Sleman. The final results in this research is a physical activity model through a circuit game consisting of 1) preparing places and equipment, 2) initial/warming up activities, 3) Core Activities consisting of 5 posts games namely Lampu Lalu Lintas, Topi Kerucutku, Balap Engklek, Tongkat Berjalan, and Terowongan Bola, 4) closing activities/cooling down.
\end{abstract}

Corresponding address : Sport Education, Faculty of Sport

Science, Universitas Negeri Yogyakarta, Indonesia

*Corresponding email : yudanto@uny.ac.id
ISSN 2685-6514 (Online)

ISSN 2477-331X (Print) 


\section{INTRODUCTION}

(Physical Education, Sports, and Health (PJOK) are one of the subject matter in elementary schools which is physical activity as a learning medium. The scope of PJOK: games and sports, development activities, gymnastics activities, rhythmic activities, water activities, out-of-class education, and health which are held with reference to the existing curriculum. The purpose of PJOK in elementary schools is to stimulate the growth and development of physical, mental, social, and emotional harmony in an effort to form and develop basic abilities, instill values, attitudes, and get used to a healthy life. Looking at the objectives of PJOK learning carried out in elementary schools, there is one goal related to basic movement abilities. The goal is to improve basic movement skills. The basic movement has an important role in learning physical education, basic movement abilities can be applied in various games, sports, and physical activities that are carried out daily. Movement development is one of the most important parts of the objectives in the implementation of physical education learning in elementary schools, (Ningrum \& Sukoco, 2017). Basic movement abilities consist of locomotor motion, nonlocomotor motion, and manipulative motion. Locomotor motion is a movement that is carried out accompanied by a change of place. Non-locomotor motion is a movement that is carried out without moving from place to place. While the basic manipulative motion is a movement that is done by manipulating an object by requiring the coordination of other senses. Locomotor motion is the main basis for moving a person's position to move from one place to another, (Hyungmin \& Johan, 2012) The development of basic movement skills is important for elementary school students. The development of basic locomotor movements in elementary school-aged children, especially the lower class, includes being able to run faster, maintain balance in walking on the catwalk and perform jumps and jumps with media such as jumping rope, jumping cones, and blocks. The basis for developing basic locomotor abilities for lower grade students is found in Basic Competency 4.1 which contains practicing basic locomotor movements in accordance with the concepts of body, space, effort, and connectedness in various forms of simple and or traditional games.

Developing basic movement skills, students do not forget to pay attention to the age of the child and adjust the stage of growth and development of the child. Where in elementary school-age is the age of children playing. Through playing, the mind is stimulated to utilize its emotional, social, and physical aspects. Games and sports are one of the media for children's movement in physical education learning, through games children will more easily know themselves, are happy with movement, and will do it with enthusiasm. The game is a tool for children to explore their world, from what they do not know to what they know and from what they cannot do, until they are able to do it. So, the play has important values and characteristics in the progress of daily development for a child. Therefore, developing basic movement skills in students can be done with a variety of interesting activities for elementary school students, especially lower grade students can be given in the form of games. This is in accordance with the opinion Yudanto (2005), The best way to develop basic movement skills in elementary school is with a playful approach because childhood is a time that loves to play. Playing is one of the strategies in teaching physical education 
material which is expected to be able to develop students according to the educational goals to be achieved (Anggraeni \& Sutiyarsih, 2018).

The forms of games that will be given to students to develop basic movement skills, especially basic locomotor movements are various, one game models involving locomotor motion is circuit games, circuit games are games that consist of several posts in it, their students will do all the games at the post so that children do not get bored and the basic locomotor movements will be trained to the maximum because at each post the games are different and the games have elements of walking, running, jumping and jumping focusing on basic locomotor movements. The results of observations from one of the Karangjati State Elementary Schools related to learning basic movements, especially locomotor basic movements in students are not optimal. This can be seen when the teacher gives orders to walk in a straight line, there are still students who make mistakes by not being able to maintain balance so they don't step on a straight line when the teacher gives orders to run past the cones arranged in a zig-zag arrangement, students do not pass through the various cones that are arranged in a row. should have been skipped, when the teacher gave the order to jump race the students made the wrong jump and had not succeeded in making the jump as a whole. In addition, it can be seen that during learning many students are less enthusiastic, less enthusiastic, and disobedient to the teacher's orders, students run on their own accord, during learning, some students do not want to continue the lesson. Teachers have used game models in learning, but other game models that are more varied and interesting are still needed to be used in basic movement learning. This causes students to feel less interested in participating in activities. Of course, this must receive attention from the teachers so that it does not affect the development of basic locomotor movement abilities. One of the learning models used based on these observations is a circuit game model. Circuit games here have advantages where students are required to move actively in various posts presented in the game so that children will be more enthusiastic, variations in the game are different for each post so that students do not feel bored, thus the basic locomotor movements that are developed are formed to the maximum, and students are trained will be endurance to be able to follow the whole game in the post. Based on some of the basic locomotor movement problems above, it is necessary to develop: "Model of Physical Activity through Circuit Games to Develop Basic Locomotor Movement Ability of Lower Grade Students".

\section{METHODS}

The development procedure is the steps that must be followed before producing a product. Borg and Gall, (1983) stated that basically, research and development procedures consist of two main objectives, namely developing a product (as a development function) and testing the effectiveness of the product in achieving its objectives (validation function). Research and development procedures or steps do not have to use standard steps that must be followed, but each developer can choose and determine the most appropriate steps for his research based on the conditions and constraints he faces. The procedure or steps used in this research use five main steps or procedures, namely: (1) preliminary study and planning stage; (2) product development stage; (3) expert validation stage; (4) trial phase; and (5) product revision.

The preliminary study and planning stages were carried out by conducting an analysis related to problems related to the 
development of basic locomotor movement abilities in elementary schools, several problems were found, including: (1) students' basic locomotor movement abilities were still not optimal, (2) the teacher was not optimal in developing a game model in locomotor motion activities, and (3) a game-based learning model is needed that is packaged in an attractively.

The initial product development stage is carried out by analyzing the objectives of developing basic locomotor movement abilities, understanding lower grade elementary school students, analyzing and identifying various types of locomotor basic movement abilities, and compiling the initial product of physical activity models through circuit games to develop basic locomotor movement abilities. The basic locomotor skills developed are: walking, running, jumping, and jumping. The following are the types of basic locomotor movements developed:

Table 1. Types and forms of basic locomotor movement physical activities

\begin{tabular}{|c|c|c|}
\hline No & $\begin{array}{c}\text { Kinds of } \\
\text { basic } \\
\text { locomotor } \\
\text { movements }\end{array}$ & Kinds of activities \\
\hline 1. & Walk & $\begin{array}{l}\text { The ability to lose } \\
\text { balance and return it } \\
\text { alternately when moving } \\
\text { forward in an upright } \\
\text { position }\end{array}$ \\
\hline 2. & Run & $\begin{array}{l}\text { The ability to move the } \\
\text { legs quickly alternately, } \\
\text { in an instant, both feet } \\
\text { left the earth before one } \\
\text { leg immediately rested } \\
\text { again }\end{array}$ \\
\hline 3. & Jump & $\begin{array}{l}\text { The ability to eject the } \\
\text { body into the air causes } \\
\text { the body to come off } \\
\text { contact from the ground } \\
\text { or tools and } \\
\text { momentarily creates a } \\
\text { floating phase, with the } \\
\text { focus on using one foot } \\
\text { at the time of the jump. }\end{array}$ \\
\hline
\end{tabular}

\begin{tabular}{ll}
\hline $4 . \quad$ Leap & The ability to eject the \\
body into the air causes \\
the body to come off \\
contact from the ground \\
or tools and \\
momentarily creates a \\
floating phase, with a \\
focus on using two feet \\
when jumping
\end{tabular}

\section{Participants}

The validation used in the expert validation test is based on content validity. Content validity refers to how far the test measures the entire subject area and the behavior to be measured. This means that the test must be comprehensive, relevant, and not outside the limits of the measurement objectives, (Ngatman \& Andriyani, 2017). Physical activities through circuit games to develop basic locomotor movement skills have been systematically arranged by following per under the preparation steps that refer to theoretical studies. The preparation is carried out starting from the elaboration of the concept which is then formulated into a conceptual definition. The next step is to formulate the various basic locomotor abilities that will be developed through circuit games. The steps that have been taken above have led to content validity. To find out whether the content and substance of the physical activity material used represents the content to be measured or intended, validation is carried out by experts who have expertise in the field of Motor Learning and Motor Development.

Besides that, it also involved two practitioners from elementary school teachers to provide input related to the preparation of physical activities through circuit games to develop the basic locomotor movement abilities. Thus, in terms of content and substance, it can be said that it has fulfilled the requirements as physical activity through circuit games to develop the basic locomotor movement abilities that will be developed. The trial 
phase was carried out to get feedback and product revisions so that later a final product in the form of physical activity was produced through circuit games to develop basic locomotor movement abilities for lower grade elementary school students. Small-scale trials were conducted on lower grade students (grades 1,2, and 3) at SD Negeri Karangjati Sleman (12 students) and large-scale trials were conducted at SD Negeri Mlesen (16 studens) and MI Husnayain Sleman (30 students). Revisions are made based on input from experts and practitioners.

\section{Sampling Procedures}

This study used a purposive sampling technique where the sample is taken with a specific purpose. The subjects of this research are earlier elementary student. The sample consist of 12 students at SD Negeri Karangjati Sleman, 16 students at SD Negeri Mlesen and 30 students at MI Husnayain Sleman.

\section{Materials and Apparatus}

The data obtained in this research and development are numerical data and data verbal (descriptive sentences in writing). Numerical data were obtained from the use of the acceptability rating scale given to each expert and practitioner. Verbal data were obtained from suggestions, comments, or criticisms written in the assessment instruments of experts and practitioners. The data collection instrument used a questionnaire guideline. Questionnaires are used to obtain or solicit information from material experts and practitioners.

\section{Design or Data Analysis}

Meanwhile, the data analysis technique used in this research and development consists of two types, namely numerical analysis, and verbal analysis. The numerical analysis uses the range obtained from the interpretation scale. A verbal analysis is done by grouping and compiling the results of input, suggestions, and criticisms from experts and practitioners. This research is a model development, the model can be said to be acceptable and used must be tested for validation and reliability. The validation used in the expert validation test is based on content validity. Game model reliability testing circuits and to develop basic locomotor movement skills for lower grade elementary school students using observational reliability or by finding the coefficient of agreement among observers. Observation reliability testing refers to the notion that determining the reliability of the instrument by using agreement among several observers or judges. To find crude index agreement, Kautsar (2019), with the following formula:

$\mathrm{IKK}=\mathrm{n}: \mathrm{N}$

Description:

IKK : Crude Index Agreement

\section{RESULT}

The research and development process as well as testing produces products in the form of physical activity through circuit games to develop basic locomotor movement abilities. The results of the study have developed 5 (five) kinds of physical activity consisting of: Lampu Lalu Lintas, Topi Kerucutku, Balap Engklek, Tongkat Berjalan, dan Terowongan Bola. The results of the assessment from experts and practitioners/teachers obtained several inputs related to physical activity through circuit games to develop basic locomotor movement abilities. Inputs and suggestions from experts and practitioners/teachers are presented in table 2 . 
Table 2. Feedback and suggestions from experts and practitioners/teachers

\begin{tabular}{|c|c|c|}
\hline No & Games & Suggestion \\
\hline 1. & $\begin{array}{l}\text { Lampu Lalu- } \\
\text { Lintas }\end{array}$ & $\begin{array}{l}\text { the field line is added } \\
\text { with a cone so that } \\
\text { when students walk } \\
\text { there will also be an } \\
\text { element of jumping }\end{array}$ \\
\hline 2. & $\begin{array}{l}\text { Topi } \\
\text { Kerucutku }\end{array}$ & $\begin{array}{l}\text { when students go } \\
\text { through a straight line, } \\
\text { students run, cones may } \\
\text { be held, while when a } \\
\text { zigzag passes through } \\
\text { cones, they are placed } \\
\text { on top of students' } \\
\text { heads, they must walk, } \\
\text { cones should not be } \\
\text { held and fall }\end{array}$ \\
\hline & $\begin{array}{l}\text { Balap } \\
\text { Engklek }\end{array}$ & $\begin{array}{l}\text { When running foward } \\
\text { right ankle balance or } \\
\text { walking left ankle }\end{array}$ \\
\hline & $\begin{array}{l}\text { Tongkat } \\
\text { Berjalan }\end{array}$ & $\begin{array}{l}\text { the distance between } \\
\text { students to be clarified } \\
\text { to avoid hitting his } \\
\text { friend's feet }\end{array}$ \\
\hline & $\begin{array}{l}\text { Terowongan } \\
\text { Bola }\end{array}$ & $\begin{array}{l}\text { running forward while } \\
\text { jumping back to add to } \\
\text { the jumping element }\end{array}$ \\
\hline
\end{tabular}

Small-scale trials were conducted on lower grade students (grades 1, 2, and 3) at SD Negeri Karangjati Sleman and large-scale trials were conducted at SD Negeri Mlesen and MI Husnayain Sleman. Testing the reliability of the circuit game model to develop basic locomotor movement skills for lower grade elementary school students using observational reliability or by looking for coefficients of agreement among observers. Observation reliability testing shows the understanding that determines the reliability of the instrument by using an agreement between several observers or judges. To find reliability by looking for indeks used Crude Index Agreement. The results of the reliability test of the circuit game model to develop basic locomotor movement skills for lower grade elementary school students can be seen in table 3 .

Table 3. Crude index agreement each game.

\begin{tabular}{clc}
\hline No & Games & $\begin{array}{c}\text { Correlation } \\
\text { Coefficient }\end{array}$ \\
\hline 1. & $\begin{array}{l}\text { Lampu Lalu- } \\
\text { Lintas }\end{array}$ & 0,75 \\
\hline 2 & $\begin{array}{l}\text { Topi } \\
\text { Kerucutku }\end{array}$ & 0,75 \\
\hline 3. & $\begin{array}{l}\text { Balap } \\
\text { Engklek }\end{array}$ & 0,81 \\
\hline 4. & $\begin{array}{l}\text { Tongkat } \\
\text { Berjalan }\end{array}$ & 0,75 \\
\hline 5. & $\begin{array}{l}\text { Terowongan } \\
\text { Bola }\end{array}$ & 0,81 \\
\hline
\end{tabular}

\section{The final product}

The model of physical activity through circuit games is carried out coherently from preparing the yard/field to be used, circuit games, then proceeding with initial/warm-up activities, core activities, and closing/cooling off. Here's a further explanation.

1. Preparing the page/field and game tools

This circuit game requires a fairly wide range of motion. Ensure that the space used allows for circuit play. In addition to the place, also pay attention to the tools used in the circuit game, which are arranged according to the posts used. The layout of each post adapts to the existing field and tools.

\section{Warming up}

The initial activity of students before carrying out activities is invited to pray and is a warm-up activity (15 minutes) to prepare the child's physical condition. The aim is to increase body temperature and flex the child's limbs so that they are not stiff and minimize the occurrence of injuries when doing locomotor physical activities. Warm-up carried out by children 
and teachers as a guide for simple movements.

\section{Activities}

The main activity is carried out for 50 minutes. The core activity is the implementation of a game consisting of 5 posts (every 10 minutes post), which includes: Lampu Lalu Lintas, Topi Kerucutku, Balap Engklek, Tongkat berjalan, dan Terowongan Bola. Before playing the game, children are given directions about the rules and steps of the game. Children play circuit games starting from post 1 to post 5 . Students are invited to complete the activities contained in each post sequentially (starting from post 1 to the next post). The core activities through circuit games are as follows:

a. Post 1

Name of game: Lampu Lalu Lintas.

Number of players : Adapt

Place : Field

Purpose : Develop basic movement skills of walking, running, and jumping.

Rules:

- All students are in a squareshaped field where inside

- In a square, some goals are arranged randomly. Movements are carried out by students, after a signal from the teacher (green, yellow, red).

- Green = all students run inside the square in a free direction

- $\quad$ Yellow = all students walk along the edge of the square, when there is a cone the student must jump over it.

- $\quad$ Red = all students stop in place.

- When passing a randomly placed goal the student must jump over it.

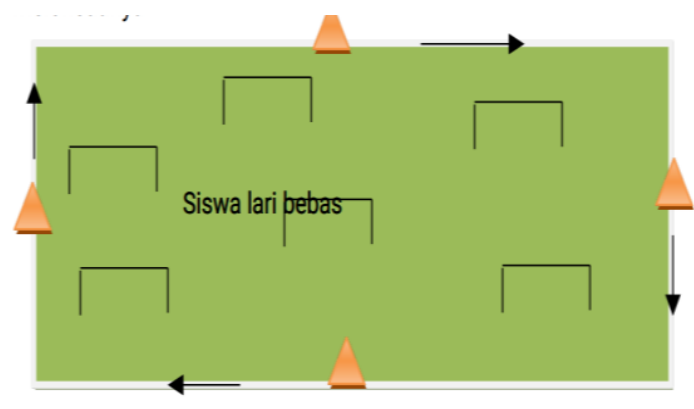

Figure 1. Field of Lampu Lalu Lintas.

b. Post 2

Name of game : Topi Kerucutku

Number of players : Adapt

Place : Field

Purpose : Develop basic walking and running skills

Rules:

- Divide students into 2 groups in rows.

- Each group is given 1 cone.

- The leading student does it first, namely placing the cone on the head and then running, the cone may be held until the student's zigzag path, the cone must not be held, maintain balance, so that the cone does not fall.

- Cones are given to the next student the same until all students do.

- The losing team gets a singing prize (folk/child/national songs).

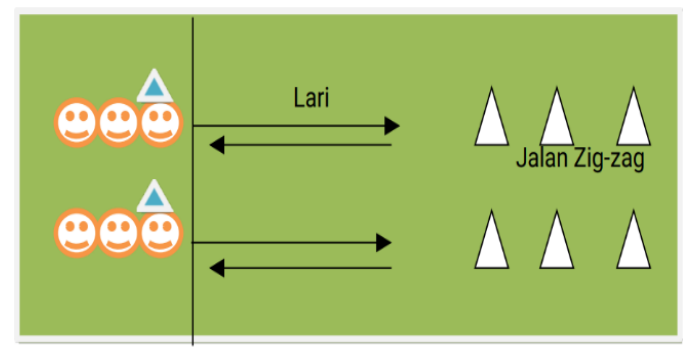

Figure 2. Field of Topi Kerucutku 
c. Post 3

Name of game

: Balap Engklek

Number of players

: Adapt

Place

: Field

Purpose : Develop

basic walking and jumping skills

Rules:

- Divide students into 2 groups in rows

- Students in the front row do the right ankle first and then take the cone to maintain balance and return to the left ankle

- After getting to the second row of children, until all students do it

- The losing group gets a singing prize.

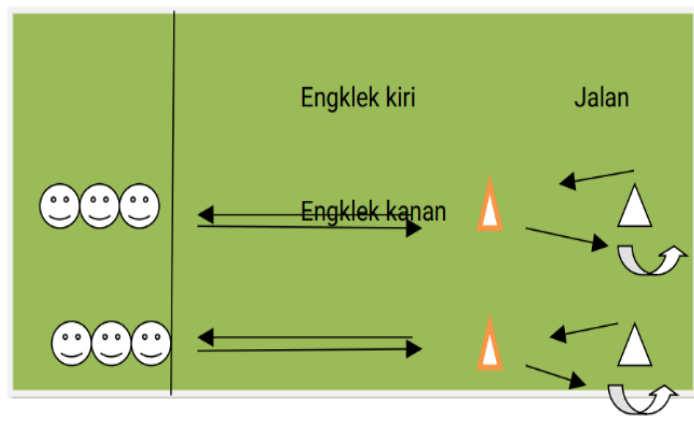

Figure 3. Field of Balap Engklek

\section{d. Post 4}

Name of game

: Tongkat Berjalan

Number of players

: Adapt

Place

: Field

Purpose

: Develop basic

running and jumping skills

Rules:

- Divide students into 2 groups. Student sitting position with straight knees close up.

- The last row student is given a stick then the student runs jump over the friends in the front row.

- After reaching the end of the student sitting, legs straightened tightly and set the distance from their friends by stretching their arms to the sides and then giving the stick to the students behind them.

- The sticks are sorted until the last student who is then taken to run jump over like the previous students.

- Done all students until the finish line sticks are included in the basket.

- The losing team is awarded a jump in place 5 times

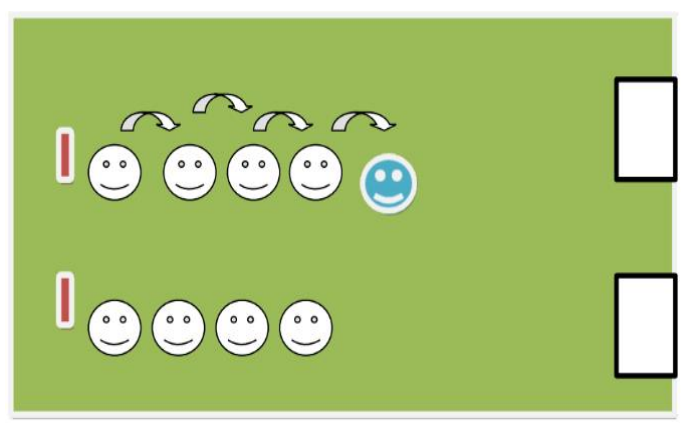

Figure 4. Field of Tongkat Berjalan.

e. Post 5

Name of game

: Terowongan Bola

Number of players

Place : Adapt

Purpose : Develop basic movement skills of running and jumping Rules:

- Divide students into 2 groups lined up with legs wide apart

- Each group is given 1 handball

- The leading student rolls the ball backward over both legs spread apart

- Arriving at the back of the student then catching the ball, carried to the end, and then jumping back to the original line to be the student at the front who is in charge of rolling the ball behind him like the first student again until all students reach the finish line

- The losing group is rewarded with running around a small field 


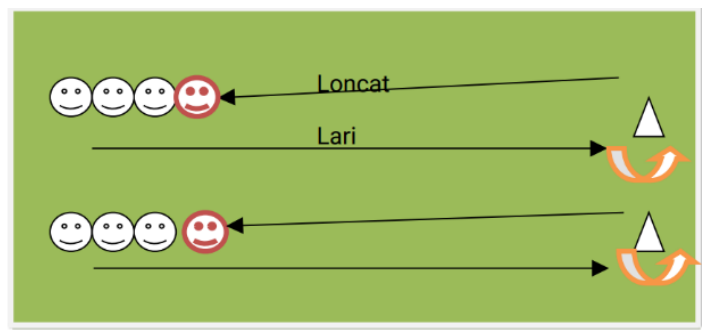

Figure 5. Field of Terowongan Bola.

\section{Cooling down}

Closing activity (5 minutes) in the form of cooling which is carried out with movements monitored by the teacher. The goal is to relax the student's muscles. Next, the teacher evaluates the activities that have been carried out and guides the children to close the activity by praying.

\section{DISCUSSION}

The results of the research related to developing a model of physical activity through circuit games to develop basic locomotor skills for lower grade students, five (5) game posts have been produced. This game is a game that is made simple by using aspects of walking, running, jumping, and jumping. The development of circuit games to develop basic locomotor movement skills is an effort to fulfill Basic Competence 4.1 which contains practicing basic locomotor movements by following per under the concepts of body, space, effort, and connectedness in various forms of simple and or traditional games. This physical activity model is made according to the characteristics of lower grade students, namely in the form of different games for each post so that students do not feel bored or bored. The development of basic motor skills is very important as a basis for developing further skills, (Olrich, 2002). Basic movement abilities also provide benefits to children related to selfconfidence in participating in various activities (B. Hands, 2012). Fundamental movement is the basis for learning and developing various technical skills in sports and physical activity throughout life. Thus, if children's basic motor competence is not developed, they are not successful in using various sports and game skills in their childhood and adolescence. (Bakhtiar, 2015). The same opinion was also conveyed in the research (Fisher et al., 2005) that basic movement ability has a significant relationship with daily physical activity. The development of basic motor skills in children has an important role in physical, cognitive, and social development, and to build the foundation for an active lifestyle, (Beth Hands \& McIntyre, 2015). This circuit game is made interesting and easy to implement in learning because in the game each post is made a simple competition. This circuit game is structured through several stages of development, including initial product development, expert validation, reliability testing, small-scale trials, large-scale trials, and final products. The final product in this development is in the form of a final product, namely a physical activity model through circuit games to develop basic locomotor skills for lower grade students which can be implemented in schools and have gone through a reliability test by getting the coefficients of each game in the range of $0.750-0.812$. Changes in students in learning activities that look more active and happy in participating in learning. This is by following per under the principle of carrying out physical motor activities, from (Rismayanthi, 2013) among others: creating a happy and fun atmosphere, the movements are varied, planned and gradual, and are arranged according to the child's needs to play and move. This pleasure arises because the forms of activity carried out are something new and are rarely done by children. The form of the game that is packaged in the form of competition in groups, makes children feel happy and demands cooperation, and gives 
encouragement to other friends in one group. This is by following per under the opinion (Sutapa, 2005) Through playing in groups, it is hoped that the individualistic nature of children can be reduced, tolerance and tolerance can be accepted which will eventually become children's habits. More according to opinion, (Rustiana, 2011) states that games or sports will have a psychological impact on students. This is due to social interaction between students and students and students with teachers.

\section{CONCLUSION}

The results of this study have developed a model of physical activity through circuit games to develop basic locomotor movement skills for lower grade elementary school students, which include: Post 1. Lampu Lalu Lintas, Post 2. Topi Kerucutku, Post 3. Balap Engklek, Post 4. Tongkat Berjalan, and Post 5 Terowongan Bola. The model is prepared by adjusting the stages of growth and development of lower-grade elementary school students. In addition, the reliability test of each game obtained coefficient values in the range of $0.75-0.81$.

\section{REFERENCES}

Anggraeni, D., \& Sutiyarsih, S. (2018). Peningkatan hasil belajar gerak dasar melempar melalui pendekatan bermain. Jurnal Pendidikan Jasmani Indonesia, 14(1), 11-17. https://doi.org/10.21831/jpji.v14i1.2134 0

Bakhtiar, S. (2015). Merancang Pembelajaran Gerak Dasar Anak. UNP Press.

Fisher, A., Reilly, J. J., Kelly, L. A., Montgomery, C., Williamson, A., Paton, J. Y., \& Grant, S. (2005). Fundamental movement skills and habitual physical activity in young children. Medicine and Science in Sports and Exercise, 37(4), 684-688.
https://doi.org/10.1249/01.MSS.000015 9138.48107.7D

Hands, B. (2012). How fundamental are fundamental motor skills? EDN 226 Reader: Teaching Health \& Physical Education in the Primary Schools, 19(January 2012), 14-17.

Hands, Beth, \& McIntyre, F. (2015). Assessment of fundamental movement skills in Australian children: the validation of a Fundamental Motor Skills Quotient (FMSQ). Malaysian Journal of Sport Science and Recreation, 11(1), 1-12.

Hyungmin, P., \& Johan, S. (2012). The relation between basic movement skills and perceptual-motor skills in 5 to 7 years old children. European Journal of Neuroscience, 4(1), 57-65.

Kautsar, A. W. (2019). Analisis Keseimbangan Antara Buku Ajar Matematika Terhadap Komponen Literasi Matematika Dengan Pengembangan Kurikulum 2013. 711717.

Mahendra, A.(2015). Model Pendidikan Gerak. Bandung: Prodi PGSD Penjas FPOK UPI. hlm. 67-75 p.27-35

Ngatman, \& Andriyani, F. D. (2017). Tes dan Pengukuran untuk Evaluasi dalam Pembelajaran Pendidikan Jasmani dan Olahraga. Yogyakarta: Fadilatama.

Ningrum, N. F. M., \& Sukoco, P. (2017). Pengembangan model permainan untuk meningkatkan perseptual motorik dan perilaku sosial siswa sekolah dasar kelas bawah. Jurnal Keolahragaan, 5(2), 171. https://doi.org/10.21831/jk.v5i2.7905

Olrich, T. W. (2002). Assessing Fundamental Motor Skills in the Elementary School Setting: Issues and Solutions. Journal of Physical Education, Recreation \& Dance, 73(7), 26-28. https://doi.org/10.1080/07303084.2002. 10607843

Rismayanthi, C. (2013). Mengembangkan Keterampilan Gerak Dasar Sebagai Stimulasi Motorik Bagi Anak Taman Kanak-Kanak Melalui Aktivitas Jasmani. Jurnal Pendidikan Jasmani Indonesia, $\quad 9(1), \quad 64-72$. https://journal.uny.ac.id/index.php/jpji/a rticle/view/3065 
Rustiana, E. R. (2011). Efek Psikologis dari Pendidikan Jasmani ditinjau dari Teori Neurosains dan Teori Kognitif Sosial. Efek Psikologis Dari Pendidikan Jasmani Ditinjau Dari Teori Neurosains Dan Teori Kognitif Sosial, 1(2). https://doi.org/10.15294/miki.v1i2.2035

Sutapa, P. (2005). Model Pengembangan Motorik Anak Prasekolah. Jurnal Pendidikan Jasmani Indonesia, (2) 1, 27-38.

Yudanto. (2005). Pengembangan Gerak Dasar Lari dan Lompat Melalui Pendekatan Bermain Di Sekolah Dasar. Jurnal Pendidikan Jasmani Indonesia, 3(1), 6777. 